\title{
PENGEMBANGAN MODUL PEMBELAJARAN SENI RUPA KOMPETENSI DESAIN POSTER UNTUK SMA
}

\author{
Nurfadilah, Irfan Arifin, Abd. Aziz Ahmad \\ Prodi Pendidikan Seni Rupa, Fakultas Seni dan Desain, Universitas Negeri Makassar \\ nurfadilah262@gmail.com \\ irfan.arifin@unm.ac.id \\ abdazizahmad@unm.ac.id
}

\begin{abstract}
Abstrak
Penelitian ini bertujuan: untuk membuat modul pembelajaran desain poster yang mengacu pada model pengembangan 4-D. Modul ini diperuntukkan bagi siswa Sekolah Menengah Atas, berisi materi tentang teknik mendesain poster. Responden yang terlibat pada penelitian pengembangan ini adalah 2 (dua) orang yaitu ahli materi dan ahli media. Data yang digali dalam penelitian ini adalah data validasi dari dosen ahli materi dan ahli media berupa aspek isi materi, aspek tampilan sampul (cover), dan aspek tampilan isi. Analisis data pada penelitian ini menggunakan teknik analisis deskriptif kuantitatif yang dikonversikan ke data kualitatif. Hasil penelitian menunjukkan bahwa nilai yang diperoleh dari validasi ahli terhadap aspek isi, aspek tampilan sampul (cover), dan aspek tampilan isi pada modul yang dikembangkan keseluruhan masuk dalam kategori bagus dan jelas, dengan rata-rata nilai aspek isi 4.43 atau 34,1\%, aspek tampilan sampul 4.14 atau $31.8 \%$, dan aspek tampilan isi 4.13 atau $34.1 \%$ yang jika dikonverskan dari rata-ratanya 4.23 untuk keseluruhan aspek modul mendapat nilai B dengan ketegori "Jelas dan Bagus". Sesuai dengan kriteria yang telah ditentukan, yaitu jika hasil penilaian ahli materi dan media dinyatakan baik maka produk yang dikembangkan telah memenuhi persyaratan dan layak digunakan sebagai media pembelajaran desain poster untuk siswa Sekolah Menengah Atas.
\end{abstract}

Kata kunci: Pengembangan; Modul; Pembelajaran; Desain Poster

\section{PENDAHULUAN}

Proses belajar mengajar pada hakikatnya adalah proses komunikasi, yaitu proses penyampaian pesan dari sumber melalui saluran/media tertentu ke penerima pesan. Pesan, sumber pesan, saluran/media dan penerima pesan adalah komponen-komponen proses komunikasi. Pesan yang akan dikomunikasikan adalah isi ajaran atau didikan yang ada dalam kurikulum.

Pada pembelajaran seni budaya, sebagian besar guru kesulitan memberikan materi pembelajaran mendesain poster dikarenakan terbatasnya media serta sarana dan prasarana sekolah yang tidak memadai. Selain itu kurangnya guru yang disiplin ilmunya tentang seni dan desain juga menjadi penyebab utama sulitnya meberikan materi pembelajaran tentang mendesain poster.

Desain poster merupakan media komunikasi visual yang tergolong dalam pembelajaran seni rupa. Poster sendiri dianggap sebagai karya desain grafis yang paling dekat dengan seni rupa jika dibandingkan dengan berbagai cabang desain lainnya. Hal tersebut dikarenakan dalam proses berkaryanya memanfaatkan berbagai unsur rupa seperti warna, bidang, garis, gambar, fotografi, dan huruf. Unsur-unsur tersebut dirangkai menjadi satu kesatuan dengan tata cara tertentu agar dapat menyampaikan pesan secara efektif. Keberadaan poster hampir dikenal oleh seluruh lapisan masyarakat. Sifat dan karakternya menjamin efktivitas dalam menyampaikan informasi kepada masyarakat. Beberapa pendapat mengatakan bahwa poster disebut juga plakat, lukisan atau gambar yang dipasang di dinding atau permukaan lain agar mendapat perhatian yang cukup besar sebagai suatu media yang memenuhi kebutuhan praktis atau fungsional manusia. Selain itu juga dibutuhkan keterampilan manual, ilmu desain, dan penguasaan aplikasi desain dalam pembuatannya.

Kemampuan dan keterampilan menggambar manual maupun menggunakan aplikasi desain pada komputer bukanlah 
jaminan siswa mampu menyusun dan menata layout dalam karya poster dengan baik. Melainkan dibutuhkan kepekaan artistik dan pengalaman estetis yang matang dalam hal desain. Toekio (2007: 80) mengatakan bahwa bidang komunikasi grafis merupakan bagian dari ilmu seni yang dimanfaatkan untuk berkomunikasi. Oleh sebab itu, memiliki wawasan mengenai teori komunikasi, keterampilan, dan kepekaan mengolah unsur rupa atau desain sangat disyaratkan sebelum masuk dalam bidang ini, maka pengembangan modul terkait desain poster dalam pembelajaran seni budaya patut dilakukan, demi meningkatkan pengetahuan, keterampilan, kepekaan, dan pengalaman estetis siswa dalam kaitannya dengan desain poster.

Tujuan penelitian ini adalah Untuk mengembangkan modul pembelajaran desain poster bagi siswa Sekolah Menengah Atas, yang diharapkan dapat menjadi salah satu solusi atas permasalahan keterbatasan media dan penguasaan materi desain poster di sekolah. Disebutkan ada berbagai jenis dan metode penelitian salah satunya dalah metode penelitian pengembangan. Definisi penelitian dan pengembangan merupakan pendekatan penelitian untuk menghasilkan produk baru atau menyempurnakan produk yang telah ada. Jadi penelitian pengembangan merupakan metode untuk menghasilkan produk tertentu atau menyempurnakan produk yang telah ada serta menguji keefektifan produk tersebut (Sukmadinata, 2010: 169).

Endnotes (dalam Putra, 2015: 70) mendefinisikan pengembangan sebagai aplikasi sistematis dari pengetahuan atau pemahaman, diarahkan pada produksi bahan yang bermanfaat, perangkat, sistem atau metode, termasuk desain, pengembangan dan peningkatan prioritas serta proses baru untuk memenuhi persyaratan tertentu.

Pengembangan media pembeajaraan oleh Vembriarto (1976:22) disebutkan dalam bentuk modul yang merupakan praktek pengajaran yang memuat satu unit konsep dari bahan ajar. Pengajaran modul merupakan suatu proses pengajaran individual yang memungkinkan siswa menguasai satu unit bahan pelajaran sebelum dia beralih kepada unit berikutnya. Modul disajikan dalam bentuk yang bersifat self-instructional. Masing- masing siswa dapat menentukan kecepatan dan intensitas belajarnya masing-masing.

Nasution (2008:205) pengajaran modul memiliki tujuan sebagai berikut; 1) Membuka kesempatan bagi siswa untuk belajar menurut kecepatannya masing-masing. 2) Memberikan kesempatan bagi siswa untuk belajar menurut caranya masing-masing, oleh sebab mereka menggunakan teknik yang berbeda-beda untuk memecahkan masalah tertentu berdasarkan latar belakang pengetahuan dan kebiasaan masing-masing; 3) Memberi pilihan dari sejumlah besar topik dalam rangka suatu mata pelajaran, mata kuliah, bidang studi atau disiplin bila kita anggap bahwa pelajar tidak mempunyai pola minat yang sama atau motivasi yang sama untuk mencapai tujuan yang sama. 4) Memberikan kesempatan bagi siswa untuk mengenal kelebihan dan kekurangannya dan memperbaiki kelemahannya melalui modul remidial, ulangan-ulangan atau variasi dalam cara belajar.

Haling, 2007: 3-4) mengemukakan bahwa: Pada dasarnya tujuan belajar terdapat tiga jenis, yaitu: a) untuk mendapatkan pengetahuan, yaitu suatu cara untuk mengembangkan kemampuan berpikir bagi anak untuk memperoleh pengetahuan dan kemampuan berpikir. Dengan tujuan belajar ini akan lebih tepat sistem presentasi atau pemberian tugas materi pembelajaran, b) untuk menanamkan konsep dan keterampilan, yaitu suatu cara belajar menghadapi dan menangani objek-objek secara fisik dan psikis. Pencapaian tujuan belajar ini cenderung dilakukan dengan cara pendemonstrasian, pengamatan, dan pelatihan, c) untuk pembentukan sikap, yaitu suatu kegiatan untuk menumbuhkan sikap mental, perilaku, dan pribadi anak. Pencapaian tujuan belajar ini, dengan cara pemberian contoh perilaku yang perlu ditiru atau tidak, dengan mengarahkan anak dalam kegiatan mengamati, meniru, dan mencontoh.

Media pendidikan merupakan seperangkat alat bantu atau pelengkap yang digunakan oleh guru atau pendidik dalam rangka berkomunikasi degan siswa atau peserta didik. Alat bantu itu disebut media pendidikan, sedangkan komunikasi adalah sistem penyampaiannya. Dengan demikian ada perbedaan antara teknologi pendidikan dengan media pendidikan. Media pendidikan itu, 
banyak dan bervariasi, sedangkan teknologi pendidikan itu menekankan kepada pendekatan teknologis dalam pengelolaan pendidikan. Teknologi pendidikan mengintegrasikan aspek manusia, proses prosedur, dan peralatan Danim (2010: 7-8).

Menurut Sadiman, dkk (2009: 11-12) mengemukakan bahwa: Proses belajar mengajar pada hakikatnya adalah proses komunikasi, yaitu proses penyampaian pesan dari sumber melalui saluran/media tertentu ke penerima pesan. Pesan, sumber pesan, saluran/media dan penerima pesan adalah komponen-komponen proses komunikasi. Pesan yang akan dikomunikasikan adalah isi ajaran yang atau didikan yang ada dalam kurikulum. Sumber pesannya bisa guru, siswa, orang lain ataupun penulis buku dan produser media. Salurannya adalah media pendidikan dan penerima pesannya adalah siswa atau guru juga.

Hamalik (dalam Arsyad, 2013: 19-20) mengatakan bahwa: Pemakaian media pembelajaran dalam proses belajar mengajar dapat membangkitkan keinginan dan minat yang baru, membangkitkan motivasi dan rangsangan kegiatan belajar, dan bahkan membawa pengaruh -pengaruh psikologis terhadap siswa. Pengaruh media pembelajaran pada tahap orientasi pembelajaran akan sangat membantu keefektifan proses pembelajaran dan penyampaian pesan dan isi pembelaran pada saat itu. Selain membangkitkan motivasi dan minat siswa, media pembelajaran juga dapat membantu siswa meningkatkan pemahaman, menyajikan data dengan menarik dan terpercaya, memudahkan penafsiran data, dan memadatkan informasi.

Sukmadinata (dalam Soebandi, 2008: 172173) Menuliskan bahwa "Model pembelajaran adalah suatu desain yang menggambarkan proses rincian dan penciptaan situasi lingkungan yang memungkinkan siswa/atau mahasiswa berinterkasi sehigga terjadi perubahan atau pengembangan dari siswa".

Rusman (2013: 145) menyimpulkan bahwa model pembelajaran memiliki ciri-ciri sebagai berikut.

1. Berdasarkan teori pendidikan dan teori belajar dari para ahli tertentu.

2. Mempunyai misi atau tujuan pendidikan tertentu.
3. Dapat dijadikan pedoman untuk perbaikan kegiatan belajar mengajar di kelas.

4. Memiliki bagian-bagian model yang dinamakan: (a) urutan langkah-langkah pembelajaran (syntax); (b) adanya prinsip-prinsip reaksi; (c) sistem sosial; (d) sistem pendukung.

5. Memiliki dampak sebagai akibat terapan model pembelajaran.

6. Membuat persiapan mengajar (desain intruksional) dengan pedoman model pembelajaran yang dipilihnya.

Media pembelajaran yang dikembangkan ini memuat materi tentang desain poster. Irfan (2015: 56) mengemukakan definisi poster sebagai media fleksibel dimana dari segi ukuran sangat ideal, tidak terlalu besar dan tidak terlalu kecil, bisa dipasang dimana saja, dan cocok untuk kegiatan apa saja. Berdasarkan definisi tersebut, maka dapat disimpulkan bahwa poster adalah media yang luwes atau mudah disesuaikan dengan kebutuhan atau kegiatan apa saja dengan ukuran sedang dan dapat dipasang dimana saja.

Adityawan (2010: 48) mengemukakan bahwa: Poster adalah media promosi yang relatif paling sederhana: terdiri dari satu lembaran tanpa lipatan yang dicetak satu muka. Media poster diciptakan sebagai sarana komuikasi untuk khalayak umum di tempat terbuka. Karenanya, poster harus memiliki ukuran yang lebih besar dengan penampilan yang menarik perhatian orang yang sedang berjalan. Kebutuhan ini menyebabkan berkembangnya tipografi dari sekedar huruf yang berukuran kecil untuk mencetak buku dengan tinta hitam.

Christopher jones (dalam Sarwono \& Lubis, 2017: 2-3) memaparkan beberapa pendapat dari beberapa pakar yang menaruh perhatian pada masalah desain dan metodologi desain, antara lain: P.J Booker (Inggris 1964) mengatakan bahwa melakukan simulasi atas sesuatu yang ingin diciptakan atau dilakukan sebelum benar-benar menciptakan atau melakukan sesuatu yang di inginkan tersebut. Simulasi dilakukan berulang-ulang, seiring yang dianggap perlu sehingga dirasa akan hasil akhirnya.

Berikut ini adalah bagan kerangka pikir pada penelitian dan pengembangan modul: 


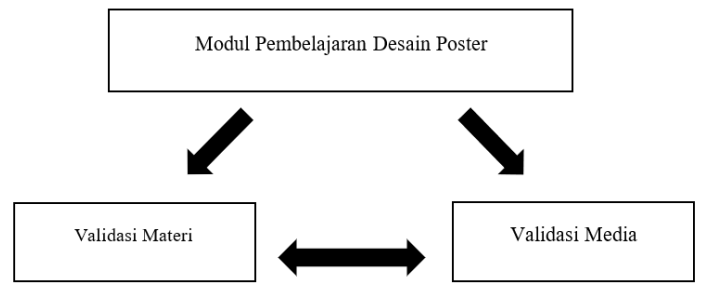

Gambar 1.

Bagan Kerangka Pikir

\section{METODE PENELITIAN}

Penelitian pengembangan media pebelajaran ini menggunakan metode penelitian dan pengembangan (Research and Development). Adapun produk yang dikembangkan pada penelitian dan pengembangan ini adalah modul pembelajaran interaktif berbasis media cetak (print out) dengan materi desain poster dan mengacu pada model penelitian 4-D yang terdiri dari empat tahapan yaitu pendefinisian (Define), perancangan (Design), pengembangan (Develop) dan penyebaran (Dessiminate). Dalam penelitian ini, pengembangan modul hanya sampai pada tahap Develop (pengembangan) dan pada tahap penyebaran (Dessiminate) akan menjadi rencana atau tujuan pada penelitian ini, artinya penelitian ini nantinya akan disebar luaskan ke sekolahsekolah dengan harapan hasil penelitian ini dapat dipergunakan dan diterima dengan baik. Penelitian jenis ini berbeda dengan penelitian pandidikan lainnya, hal tersebut dikarenakan tujuan dari penelitian ini adalah mengembangkan produk berdasarkan uji kelayakan melalui revisi dan validasi ahli hingga menghasilkan produk yang layak dijadikan sebagai media pembelajaran untuk siswa Sekolah Menengah Atas. Responden yang terlibat pada penelitian pengembangan ini adalah 2 (dua) orang yaitu ahli materi dan ahli media. Adapun data yang digali dalam penelitian ini adalah data hasil validasi dari dosen ahli materi dan ahli media berupa aspek isi materi, aspek tampilan sampul (cover), dan aspek tampilan isi. Analisis data pada penelitian ini menggunakan teknik analisis deskriptif kuantitatif yang dikonversikan ke data kualitatif.
Secara singkat, prosedur pengembangan modul pembelajaran desain poster dapat dilihat pada skema berikut:

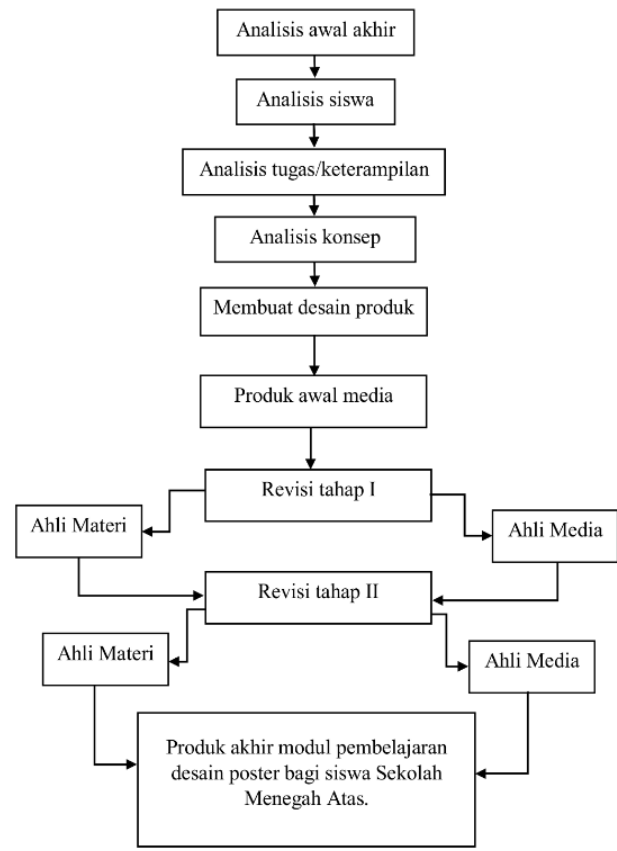

Gambar 2.

Skema Prosedur Pengembangan Modul Pembelajaran Desain Poster

Diadopsi dari Model Pengembangan 4-D Thiagarajan (1974)

Teknik pengumpulan data yang digunakan pada penelitian pengembangan modul pembelajaran ini adalah metode kajian pustaka dan dokumentasi, metode kajian pustaka ini bertujuan untuk mengumpulkan referensi yang relevan dengan cara dikutip atau dijadikan dasar dari sebuah ide penelitian pengembangan media yang akan dilakukan baik dari jurnal penelitian, buku, artikel, atau situs internet yang dapat dipercaya. selain itu, metode dokumentasi juga sangat berperan penting dalam penelitian ini karena digunakan untuk mendapatkan keterangan dan penerangan pengetahuan serta bukti yang dapat mendukung dalam penelitian pengembangan yang dilakukan. Analisis data mencakup seluruh hasil penilaian yang terkumpul dari proses valisasi para ahli berupa aspek isi, aspek tampilan sampul (cover), dan aspek tampilan isi yang dianalisis secara deskriptif kualitatif. Data yang diperoleh dari instrumen validasi dianalisis dengan cara mengkonversi data 
kuantitatif menjadi data kualitatif dengan rumus sebagai berikut:

Tabel 2. Tabel Rumus

\begin{tabular}{|c|c|c|}
\hline Nilai & Kategori & Interval Skor \\
\hline A & $\begin{array}{c}\text { Sangat } \\
\text { Tinggi }\end{array}$ & $\mathrm{X}>\mathrm{Xi}+1,80 \mathrm{Sbi}$ \\
\hline B & Tinggi & $\begin{array}{c}\mathrm{Xi}+0,60 \mathrm{Sbi}<\mathrm{X} \leq \mathrm{Xi}+ \\
1,80 \mathrm{Sbi}\end{array}$ \\
\hline C & Sedang & $\begin{array}{c}\mathrm{Xi}-0,60 \mathrm{Sbi}<\mathrm{X} \leq \mathrm{Xi}+ \\
0,60 \mathrm{Sbi}\end{array}$ \\
\hline D & Kurang & $\begin{array}{c}\mathrm{Xi}-0,80 \mathrm{Sbi}<\mathrm{X} \leq \mathrm{Xi}- \\
0,60 \mathrm{Sbi}\end{array}$ \\
\hline E & $\begin{array}{c}\text { Sangat } \\
\text { kurang }\end{array}$ & $\mathrm{X} \leq \mathrm{Xi}-1,80 \mathrm{Sbi}$ \\
\hline
\end{tabular}
75)

Adaptasi dari Sukarjo (dalam Arifin, 2011:

\section{HASIL DAN PEMBAHASAN \\ 3.1. Hasil}

Untuk melihat hasil penilaian kelayakan modul pada penelitian pengembangan ini dapat dilihat pada tahap pengembangan (develop) yang diawali dengan memberikan produk awal kepada ahli materi dan ahli media yang bertujuan untuk memperoleh data penilaian kelayakan modul dengan menggunakan angket, selain itu juga untuk memperoleh kritik dan saran terhadap modul yang dikembangkan.

Setelah data hasil validasi produk diperoleh, selanjutnya dilakukan analisis data dengan cara deskriptif kuantitatif yang dikonversikan ke datakualitatif. Berikut pemaparan hasil validasi modul:

Keseluruhan hasil penilaian ahli para ahli terhadap modul pembelajaran yang dikembangakan dapat dilihat pada tabel distribusi frekuensi penilaian keseluruhan aspek sebagai berikut:

Tabel 2. Distribusi Frekuensi Penilaian Aspek Modul

\begin{tabular}{|c|c|c|c|}
\hline $\begin{array}{c}\text { Kriteria } \\
\text { Penilaian }\end{array}$ & Skor & $\%$ & $\begin{array}{c}\text { Rata- } \\
\text { rata }\end{array}$ \\
\hline Isi & 62 & 34.1 & 4,43 \\
\hline $\begin{array}{c}\text { Tampilan } \\
\text { cover }\end{array}$ & 58 & 31.8 & 4,14 \\
\hline
\end{tabular}

\begin{tabular}{|c|c|c|c|}
\hline $\begin{array}{c}\text { Tampilan } \\
\text { isi }\end{array}$ & 62 & 34.1 & 4.13 \\
\hline Jumlah & 182 & 100 & 12.7 \\
\hline Rata-rata & & 4.23 \\
\hline Nilai & $\mathrm{B}$ \\
\hline
\end{tabular}

Berikut adalah penyajian hasil penilaian keseluruhan aspek modul oleh ahli materi dan ahli media dalam bentuk diagram:

\section{PENILAIAN MODUL}

@Aspek Tampilan Isi

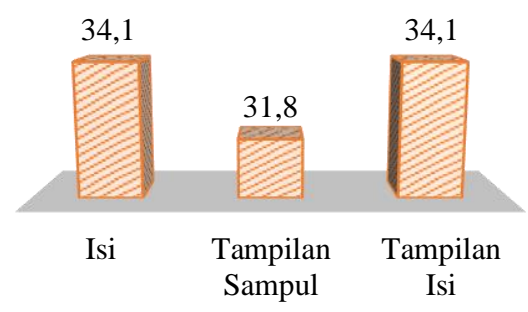

Gambar 3. Diagram Penilaian Aspek Modul

Dari hasil validasi ahli terhadap aspek isi, aspek tampilan sampul (cover), dan aspek tampilan isi pada modul yang dikembangkan, kriteria penilaian yang diberikan dapat diketahui dengan melihat jumlah rata-rata penilaian keseluruhan aspek modul seperti yang terlihat pada tabel 1. Setelah dikonversikan dari rata-rata penilaian aspek isi 4.43 atau $34.1 \%$, aspek tampilan sampul 4,14 atau $31.8 \%$, dan tampilan isi 4.13 atau $34.1 \%$ yang jika dikonverskan dari rata-ratanya 4.23 untuk keseluruhan modul pembelajaran yaitu mendapat nilai B atau dengan kategori materi dan media "Jelas dan Bagus". Hasil penilaian dari kedua ahli menunjukan produk yang dikembangkan telah memenihi persyaratan dan layak digunakan sebagai media pembelajaran desain poster untuk siswa Sekolah Menengah Atas. Walaupun demikian, kedua ahli tetap memberikan saran dan masukan untuk materi dan tampilan modul pembelajaran yang sedang dikembangkan agar produk ini layak digunakan sebagai media pembelajaran desain poster. Saran dan masukan yang dimaksud antara lain: 


\subsection{Revisi Produk}

Revisi produk dari ahli materi adalah revisi yang didasarkan pada masukan dari ahli materi berupa saran, komentar, masukkan, dan kritikan yang dijadikan acuan untuk memperbaiki dan merevisi modul pembelajaran yang sedang dikembangkan. Berikut ini adalah uraian saran, komentar, masukan, dan kritikan dari ahli materi beserta perbaikan yang telah di lkukan peneliti:

1. Item aspek materi dikurangi dan beberapa diperbaiki.

2. Pernyataan tentang ukuran media poster bahwa "BESAR" diganti menjadi "SEDANG" sebab dibandingkan dengan media lain banyak yang lebih besar.

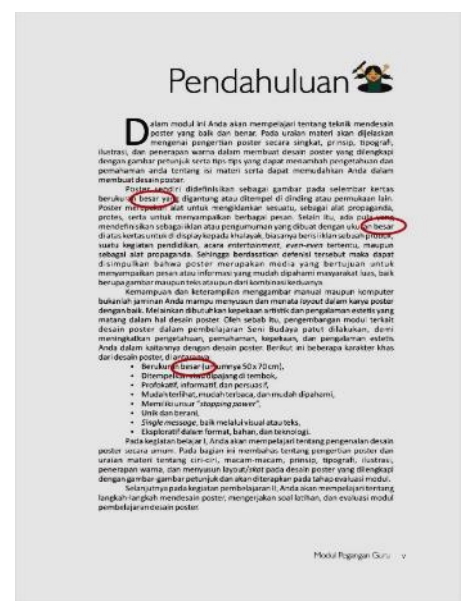

Gambar 4. Halaman Pendahuluan Modul Sebelum Direvisi

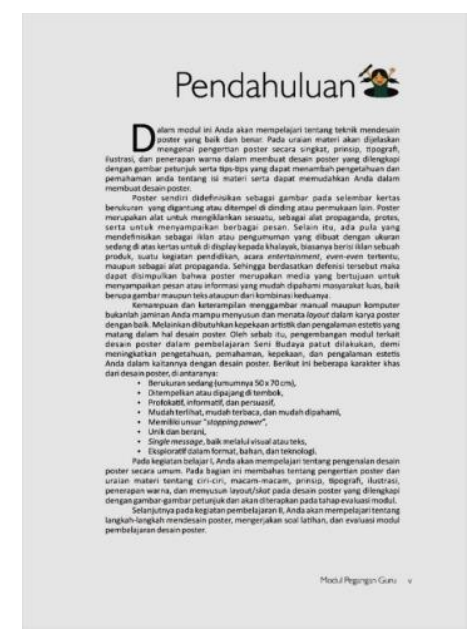

Gambar 5. Halaman Pendahuluan Modul Setelah Direvisi
- Revisi dari ahli media adalah revisi yang didasarkan pada masukan dari ahli media berupa saran, komentar, masukkan, dan kritikan yang dijadikan acuan untuk memperbaiki dan merevisi modul pembelajaran yang sedang dikembangkan. Berikut ini adalah uraian saran, komentar, masukan, dan kritikan dari ahli media beserta perbaikan yang telah dilakukan peneliti:

1. Untuk desain cover, perlu dipikirkan peruntukan modul dalam kaitannya dengan pendidikan (formal, non formal, atau informal).

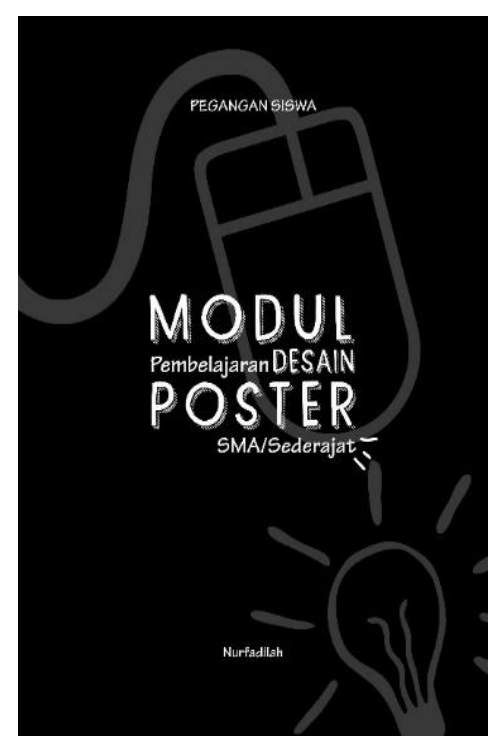

Gambar 6. Sampul Modul Sebelum Direvisi

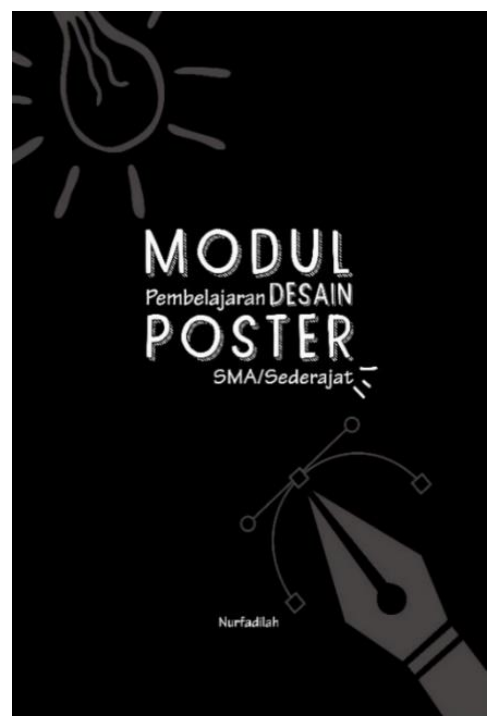

Gambar 7. Sampul Modul Setelah Direvisi 


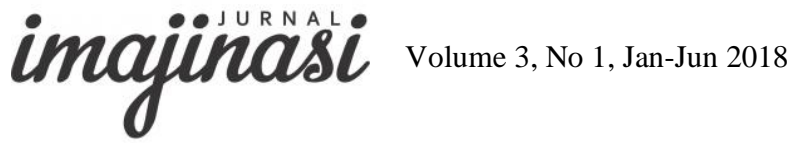

2. Untuk aspek isi, kejelasan pemisah antar paragraf.
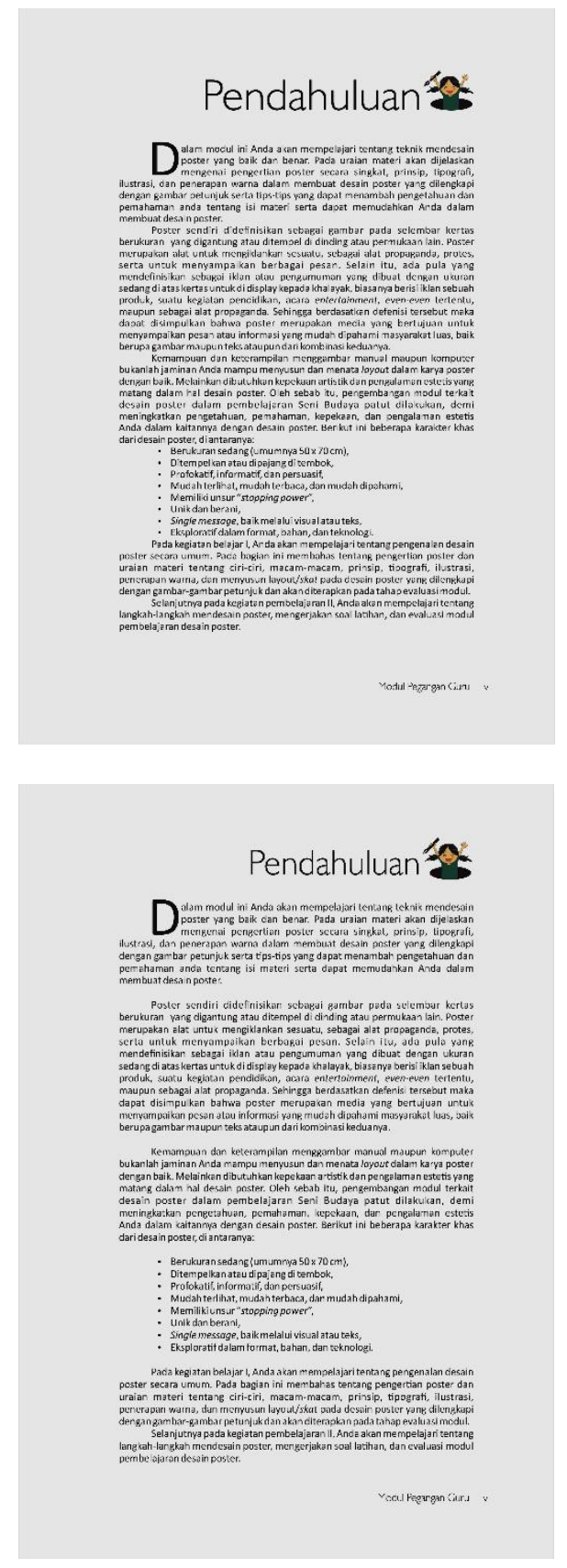

Gambar 8. Halaman Pendahuluan Sebelum dan Sesudah Direvisi

3. Pada halaman dua, biasanya berbicara peta kedudukan modul itu kaitannya dengan posisi meteri yang akan diajarkan di antara materi yang lain.

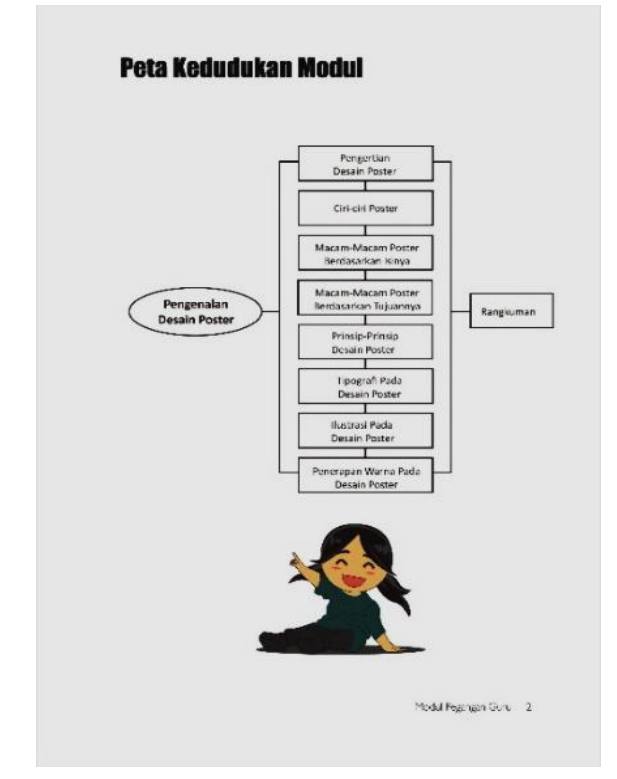

Gambar 9. Halaman Peta Konsep Sebelum Direvisi

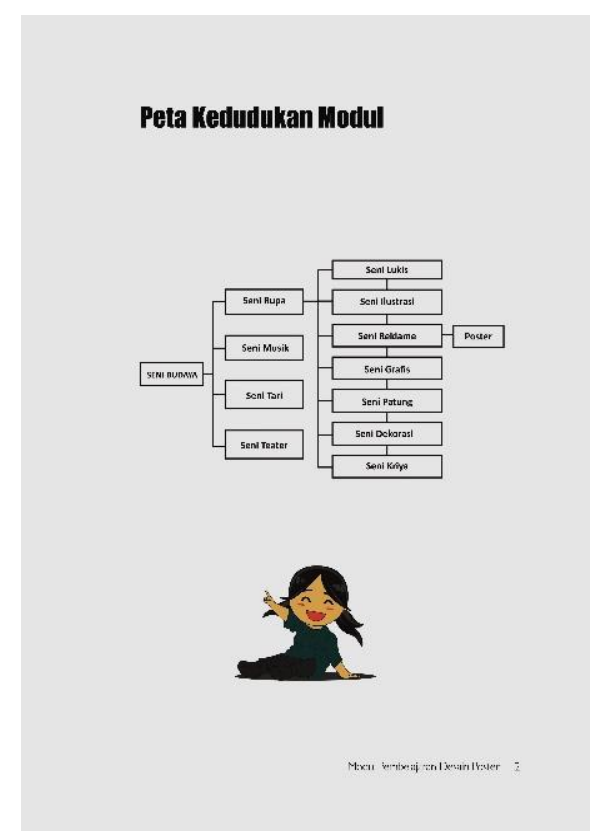

Gambar 10. Halaman Peta Konsep Sesudah Direvisi

\subsection{Pembahasan}

Pembahasan ini memaparkan keseluruhan dari hasil pengembangan produk secara rinci dan jelas. Pembahasan yang dipaparkan berupa proses dan kualitas kelayakan pada pengembangan modul pembelajaran desain poster. Perancangan modul pembelajaran ini menggunakan aplikasi CorelDRAW X7. 
Secara keseluruhan pengembangan modul ini melalui tahap pengembangan 4-D (Define, Design, Develop, dan Dessiminate). Karena keterbatasan waktu dan biaya, pengambangan ini tidak sampai pada tahap penyebaran (Dessiminate) dan hanya sampai pada tahap Develop (pengembangan), tahap penyebaran (Dessiminate) akan menjadi rencana atau tujuan pada penelitian ini, artinya penelitian ini nantinya akan disebar luaskan ke sekolahsekolah.

Penelitian pengembangan ini adalah penelitian yang bertujuan untuk menghasilkan produk berupa modul pembelajaran desain poster yang ditujukan bagi Siswa Sekolah Menegah Atas. Penelitian ini dilakukan dengan mengumpulkan berbagai referensi relevan dengan cara dikutip atau dijadikan dasar dari sebuah ide dalam penyusunan modul pada penelitian pengembangan yang dilakukan baik dari jurnal penelitian, buku, artikel, atau situs internet yang dapat dipercaya. Selain itu, juga dilakuan dokumentasi untuk mendapatkan keterangan dan penerangan pengetahuan serta bukti yang dapat mendukung dalam penelitian pengembangan yang dilakukan.

\subsubsection{Perencanaan}

Perencanaan dilakukan setelah adanya informasi dan referesi di atas. Pada tahap penelitian ini, dilakukan perumusan tujuan pengembangan yang akan dicapai dan mengumpulkan komponen-komponen awal seperti menentukan analisis kuriulum, Penentuan judul modul pembelajaran, dan penyusunan materi yang dianggap penting dalam pembelajaran desain poster pada mata pelajaran seni budaya.

Tahapan yang pertama dilakukan adalah pendefinisian (define) yaitu analisis awal dan akhir, tahapan ini bertujuan untuk menetapkan masalah dasar yang diperlukan dalam pemgembangan modul pembelajaran desan poster. Pada tahap ini ditetapkan teori yang relevan dan sesuai dengan kutikulum yang berlaku. Selanjutnya dilakukan analisis siswa untuk mengetahui telaah karakteristik siswa yang sesuai dengan rancangan dan pengembangan media pembelajaran desain poster. Karakteristik tersebut meliputi ciri siswa, kemampuan dan pengalaman siswa dalam menggunakan berbagai media atau modul pembelajaran, kemudian menentukan konsep guna untuk mengidentifikasi, merinci dan menyusun secara sistematis konsepkonsep yang relevan dalam menyusun tujuan pembelajaran berdasarkan analisis awal-akhir yang merupakan dasar-dasar dalam menyusun konsep materi yang akan digunakan. Selain itu, juga dilakukan analisis tugas/keterampilan untuk mengidentifikasian tugas/keterampilanketerampilan utama yang dimiliki dan dilakukan siswa selama proses belajar mengajar.

Tahap kedua adalah perancangan (design) yaitu penentuan judul buku dan penyusunan materi pembelajaran desain poster, yang dimana diawali dengan pendefinisian singkat tentang desain poster dan materi seputar desain poster. Selanjutnya yaitu tahap menjelajahi ide yang bertujuan untuk menciptakan sebuah ide untuk kemudian dibuatkan rancangan awal desain modul sekaligus menguraikan masalahmasalah yang dihadapi demi mendapatkan solusi yang tepat bagi perancangan modul pembelajaran. Mulai dari mengumpulkan data, membuat kerangka hingga menentukan tengah waktu untuk membuat produk.

\subsubsection{Pengembangan Format Produk Awal}

Penyajian data pada hasil pengembangan modul pembelajaran desain poster yaitu deskripsi hasil pengembangan dan data hasil validasi oleh ahli materi dan ahli media.

Deskripsi modul hasil pengembangan berupa uraian singkat tentang isi modul yang dimulai dengan pendefinisian singkat tentang poster dan materi seputar desain poster seperti ciri, macam, prinsip, tipografi, ilustrasi dan penerapan warna pada desain poster yang disertai dengan gambar-gambar petunjuk dan tips-tips yang dapat memudahkan siswa dalam membuat sedain poster.

\subsubsection{Aspek Isi Materi}

Aspek ini dimaksudkan untuk mengetahui penilaian dosen ahli materi mengenai isi materi pada modul yang terdiri dari 14 item indikator yang dapat dilihat pada tabel 7 (halaman 47). Sebagaimana yang ada pada tabel tersebut ratarata skor yang didapatkan sebesar 4.43. Angka ini jika dikonversikan kedata kualitatif maka angka tersebut masuk dalam kategori skor nilai 
A atau dengan kategori materi "Sangat Jelas". Rincian dari indikator penilaian pembelajaran ini adalah 6 item atau $42.86 \%$ isi dianggap sangat jelas, 8 item $57.14 \%$ yang dianggap jelas, hasil penilaian tersebut dapat dilihat pada lampiran 4 (halaman 72).

\subsubsection{Aspek Tampilan Sampul (Cover)}

Aspek tampilan sampul terdiri dari 14 item indikator penilaian sebagaimana yang terdapat pada tabel 9 (halaman 49). Aspek ini dievaluasi untuk mengetahui bagaimana penilaian ahli media mengenai berbagai hal yang menyangkut tampilan sampul pada modul pembelajaran yang telah dikembangkan. Dari rata-rata skor aspek tampilan sampul penilaian Ahli media didapatkan nilai 4.14 yang jika dikonversikan maka skor ini masuk dalam kategori nilai B atau dengan kategori media "Sangat bagus" hasil penilaian dari 14 indikator rincian ada 3 item atau $21.43 \%$ isi dianggap sangat bagus, 10 item $71.43 \%$ yang dianggap bagus, dan 1 item $7.14 \%$ dianggap cukup jelas. Hasil penilaian tersebut dapat dilihat pada lampiran 9 (halaman 77).

\subsubsection{Aspek Tampilan Isi}

Aspek tampilan Isi terdiri dari 14 item indikator penilaian sebagaimana yang terdapat pada tabel 11 (halaman 51). Aspek ini dievaluasi untuk mengetahui bagaimana penilaian ahli media mengenai berbagai hal yang menyangkut tampilan sampul pada modul pembelajaran yang telah dikembangkan. Dari rata-rata skor aspek tampilan sampul penilaian Ahli media didapatkan nilai 4.13 yang jika dikonversikan maka skor ini masuk dalam kategori nilai $\mathrm{B}$ atau dengan kategori madia "Bagus" hasil penilaian dari 15 indikator rincian ada 4 item atau $26.67 \%$ isi dianggap sangat jelas, 9 item $60 \%$ yang dianggap jelas, dan 2 item atau $13 \%$ isi dianggap cukup jelas. Hasil penilaian tersebut dapat dilihat pada lampiran 10 (halaman 78).

Dari hasil validasi oleh ahli terhadap aspek isi, aspek tampilan sampul (cover), dan aspek tampilan isi pada modul yang dikembangkan, dapat diketahui kriteria penilaian yang diberikan dengan melihat jumlah rata-rata penilaian keseluruhan aspek modul seperti yang terlihat pada tabel 13 .
Setelah dikonversikan dari rata-rata penilaian aspek isi 4.43 atau $34.1 \%$, aspek tampilan sampul 4,14 atau $31.8 \%$, dan tampilan isi 4.13 atau $34.1 \%$ yang jika dikonverskan dari rataratanya 4.23 untuk keseluruhan modul pembelajaran yaitu mendapat nilai $B$ atau dengan kategori materi dan media "Jelas dan Bagus". Hasil penilaian dari kedua ahli menunjukan produk yang dikembangkan telah memenihi persyaratan dan layak digunakan sebagai media pembelajaran desain poster untuk siswa Sekolah Menengah Atas, hal tersebut dapat dilihat pada lampiran 6 dan 12 (halaman 74 dan 80). Walaupun demikian, kedua ahli tetap memberikan saran dan masukan untuk materi dalam modul pembelajaran yang sedang dikembangkan agar produk ini layak digunakan sebagai media pembelajaran desain poster.

\section{SIMPULAN DAN SARAN \\ 4.1. Kesimpulan}

Berdasarkan hasil penelitian pada pembahasan di atas, maka dapat ditarik kesimpulan sebagai berikut:

1. Spesifikasi modul pembelajaran

Media pembelajaran yang dikembangkan berupa modul pembelajaran desain poster yang diperuntukkan bagi guru dan siswa Sekolah Menegah Atas. Jumlah halaman pada modul adalah 52 halaman, yang terdiri kata pengantar, daftar isi, peta kedudukan modul, peta konsep, petunjuk penggunaan modul, pendahuluan, tips, gambar ilustrasi, uraian materi, rangkuman, petunjuk soal latihan, lembar kerja, evauasi, kunci jawaban, format penilaian hasil evaluasi, glosarium, dan daftar pustaka.

2. Struktur desain pengembangan modul Pengembangan modul ini dilakukan dengan menggunakan model 4D yaitu define (pendefinisian), design (perancangan), develop (pengembangan), dan dessiminate (penyebaran). Namun hanya sampai pada tahap develop (pengembangan) yakni tahap validasi oleh ahli materi dan ahli media.

3. Dari hasil Validasi oleh ahli terhadap aspek isi, aspek tampilan sampul (cover), dan aspek tampilan isi dalam modul yang dikembangkan, keseluruhan aspek masuk 
dalam kategori bagus dan jelas. Karena itu sesuai dengan kriteria yang telah ditentukan, yaitu jika hasil penelitian ahli materi dan media menyatakan kriteria baik maka secara keseluruhan modul dikatakan layak dengan nilai yang diperoleh dari keseluruhan aspek dengan rata-rata penilaian aspek isi 4.43 atau $34.1 \%$, aspek tampilan sampul 4.14 atau $31.8 \%$, dan tampilan isi 4.13 atau $34.1 \%$ yang jika dikonversikan dari rata-ratanya 4.23 untuk keseluruhan modul pembelajaran yaitu mendapat nilai $\mathrm{B}$ atau "Jelas". Hasil penilaian dari kedua ahli menunjukan produk yang dikembangkan sudah jelas atau sudah bagus untuk sebuah modul pembelajaran desain poster.

\subsection{Saran}

Berdasarkan pembahasan pada bab sebelumnya, maka disarankan sebaiknya modul ini digunakan sebagai bahan materi pelengkap dalam mata pelajaran seni budaya, serta dapat menjadi bahan latihan membuat desain poster bagi siswa baik melalui bimbingan guru maupun secara mandiri.

\section{DAFTAR PUSTAKA}

Adityawan, A. 2010. Tinjauan Desain Grafis. Jakarta: Concept Media.

ARIFIN, I. (2011). Memahami Alur Kerja Produk Cetak (Paket Pembelajaran Buklet Elektronik Bagi Mahasiswa Peserta Mata Kuliah Grafika Program Studi Desain Komunikasi Visual Fakultas Seni dan Desain Universitas Negeri Makassar)(Doctoral dissertation, Pascasarjana).

Arsyad, A. 2013. Media Pembelajaran. Jakarta: Rajawali Pers.

Danim, S. 2010. Media Komunikasi Pendidikan. Jakarta: PT. Bumi Aksara.

Haling, A. 2007. Belajar dan Pembelajaran. Makassar: Badan Penerbit Universitas Negeri Makassar.
Irfan, I. (2015). PERPADUAN ELEMENELEMEN DESAIN PADA KARYA DESAIN POSTER MAHASISWA (Studi kasus pada Tugas poster mata kuliah Penulisan naskah Iklan DKV FSD UNM angkatan 2011). Tanra, 2(02), 54-68.

Nasution, S. (2008). Berbagai Pendekatan dalam Proses Belajar \& Mengajar. Jakarta: Bumi Aksara.

Putra, N. 2015. Research \& Development. Jakarta: Rajawali Pers.
Rusman. 2013. Model-model Pembelajaran Mengembangkan Profesionalisme Guru. Jakarta: Rajawali Pers.

Sadiman, Arief S. dkk. 2009. Media Pendidikan Pengertian Pengembangan, dan Pemanfaatannya. Jakarta: Rajawali Pers.

Sarwono, J. \& Lubis, H. 2007.Metode Riset untuk Desain Komunikasi Visual. Yogyakarta: C.V Andi

Soebandi, B. 2008. Model Pembelajaran dan Apresiasi Seni Rupa. Solo: Maulana Offset.sa

Sukmadinata, N.S. 2013. Metode Penelitian Pendidikan. Bandung: PT Remaja Rosdakarya

Vembriarto. (1976). Pengantar Pengajaran Modul. Yogyakarta: Yayasan Pendidikan Paramita. 